\title{
Does Information Technology Help Fish Marketing? A Review for A Preferability Fish Marketing in North Sumatera, Indonesia
}

\author{
Arsyad Lubis, Muhammad Akbar Siregar, Maksyum Syahri Lubis \& \\ Andre Hasudungan Lubis
}

\section{Abstract}

The integration of Information Technology in fish marketing has become a neglected issue in North Sumatera, Indonesia. As located in the Malacca Strait and the Indian Ocean, the territorial waters of North Sumatra expect to bring many benefits to both community and government in the fisheries sector. Marketing as the part of a business to interact the producers and consumers is required to achieve optimal utilization in managing fisheries catches for marine

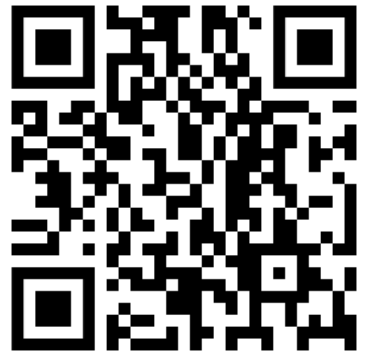
products Marketing Mix as the tactical marketing tools can be applied into IT applications and tools. Promotion, Product, Place, Price, Process, People and Physical Evidence as the 7Ps of Marketing Mix has been touched by the fashion of this technology. This paper proposed five stages should carry out to fulfil an IT-integration fish marketing. Literature review and concepts regarding the relationship between IT tools and fish marketing are critically assessed.

Keywords: Information Technology, Fisheries, Fish Marketing, Marketing Mix, North Sumatra.

\section{About Author}

Arsyad Lubis, Faculty of Social and Politic, Universitas Medan Area, North Sumatra, Indonesia

Muhammad Akbar Siregar, Faculty of Economics and Business, Universitas Medan Area, North Sumatra, Indonesia

Maksyum Syahri Lubis, Faculty of Social and Politic, Universitas Medan Area, North Sumatra, Indonesia

Andre Hasudungan Lubis (Corresponding Author), Faculty of Engineering, Universitas Medan Area, North Sumatra, Indonesia 


\section{Introduction}

Fisheries is an economic activity through the natural resources sustainably in order to benefit as much as possible for the welfare of mankind. There are several activities in a fisheries aquaculture system, starting from the production facilities procurement, production, postharvest processing and marketing. The instrument is a series of activities that are interrelated with each other. Marketing has become an important part of all activities that produce commodity or services [1]. Marketing drives a strong linkage between producers and consumers in the market. Thus, marketing activities are not only limited to marketing but also include all strategies that aim to provide satisfaction to consumers [2]. There are seven elements which play as the main consideration in preparing how to conduct a marketing process, namely: Promotion, Product, Place, Price, Process, People and Physical Evidence [3], [4]. The Marketing Mix concepts are interrelated with each other, hence it must run them in tandem and proportionally. The pattern of fish marketing in Indonesia is affected by local influences, hence require fishermen to form the different patterns in each region. Different marketing systems arise in several locations due to the marketing pattern has a great influence on all fishermen activities. Indonesia, which has a large variety of agro-ecological and socio-economic types, causes differences in patterns of small-scale business between local fisheries that cannot be avoided [5]. This also occurs in North Sumatera, the level of fish auctions is still very weak and causing there is no trade between the local traders. Thus, auction activities are needed in order to create market activities that can increase the income to the community [6]. Information Technology (IT) has become part of human life in many sectors [7], whereas marketing is catching up with this to increase performance and quality [8]. IT proposes its applications such as Social Media, Internet and Websites to capture the customers and deliver the products more efficiently [9]-[11]. IT already holding for the stock control, commercial data collection, and also marketing. IT has delivered chances for managing almost all of the activities in the fishing industry. Then, it is able to combine operational efficiency with market transparency to improve industrial competitiveness [12]. According to the Indonesian Ministry of Maritime Affairs and Fisheries, strong support from efficient technology, guaranteed product quality, and a chain of production systems are help the efficiency of producing highly competitive products. Moreover, producers will be able in marketing on their products directly to consumers without having to go through a long supply chain, hence reducing costs to the consumers. This paper is reviewing on how IT helps the fish marketing in North Sumatera, Indonesia regarding the IT tools and applications with concerning to the 7P of Marketing Mix.

\section{Concepts and Theories}

\subsection{Fish Marketing as Regional Income}

In Indonesia, Regional Income is earned by regions which are collected under regional regulations. It is sourced from the results of regional taxes, the results of regional levies, the results of separated regional wealth management, and other legitimate local revenue. Regional Income aims to provide flexibility to the regions in recovering funding in the implementation of regional autonomy as the realization of the principle of decentralization as stated in Law Number 12 of 2008 concerning Regional Government Article 15. One of living natural resources from the country is located in fisheries, both from marine fisheries including various activities such as storing, cooling, preserving and managing it. As one of the most potential sectors in Indonesia, the fisheries sector must be improved to take advantage of this potential. However, this sector received less attention from the government causing a low contribution and utilization in the Indonesian economy. Thus, a professional system in

\section{International Journal of Science and Business Email: editor@ijsab.com Website: ijsab.com}

Published By 
regulation and administration is required to achieve optimal utilization in managing fisheries catches for marine products [13].

\subsection{Marketing}

Marketing is one of the main activities directly related to consumers that need to be carried out by the company as an effort to maintain the viability of its business [3]. The main purpose of the marketing concept is to serve consumers by getting a number of profits, or it can be interpreted as a comparison between income and reasonable costs. This is different from the concept of sales which focuses on the company. Thus, marketers must provide customers with what they want to buy, with prices that represent the value of money [14]. Marketers usually integrate with the Marketing Mix. At first, the Marketing Mix included four Ps of marketing, namely Promotion, Product, Place, Price. Then, another Ps were added as the additional factors to the formula namely Process, People and Physical Evidence [3], [4].

\subsection{Marketing Mix}

Marketing Mix is a set of tools for tactical marketing tools that can be controlled, product, price, distribution, and promotion combined by the company to produce the desired response in the target market. Furthermore, the marketing mix can be used as a collection of variables that can be used by companies to influence consumer responses [3], [4], [15]. The Marketing Mix concepts are including Promotion, Product, Place, Price, Process, People and Physical Evidence. (1) Product. Things that are sold in a business both goods or services that have use value and are needed by consumers. The main key to the product both goods or services must be able to meet the consumers' needs. In addition, the product must have more value than others to easily received by consumers. (2) Promotion. A business activity that aims to deliver information to consumers to get interested in business products. In this activity, marketers must be able to change consumer perceptions to be positive about the product. (3)Place. Marketers should have attention to whether the location is quite strategic and easily visited by consumers. The product must be available in different target customer and different breadth of sales scope. (4) Price. Consumers assume that prices as the main consideration before buying some products. Marketers should follow the market dynamics in order to set prices at the right level and representing good value for money. Then, it will be received by consumers. (5) Process. In marketing, process interpreted as steps taken between marketer and consumers, including service delivered and transaction processes. (6) People. In this aspect, consumers are not the only one that involved, but also all HR including workers or business teams. This is very important because remembering all people must have different tendencies in the business. (7) Physical evidence. All in the form of equipment or devices used to support the running the business. For large-scale businesses, it requires more equipment and more complex functions and uses.

\subsection{Fish Marketing}

Marketing is a very important part of economic development, which is a stimulus for production, avoiding unnecessary fluctuations in output and prices, also reducing costs [16]. Different problems faced by fish marketers rather than others, namely: more uncertainty in fish production, fish traits are easy to damage, collecting fish from various landing centres, too many species and many patterns of demand. Thus, the fish marketing system becomes the regulator of fish production and development of the fishery sector [17], [18]. Several processes are involved in the fish marketing system, it starts with transporting fish from farmers and finally received by consumers. Preservation, transportation and marketing are

\section{International Journal of Science and Business Email: editor@ijsab.com Website: ijsab.com}

Published By 
three important links in the fish production and consumption chain that connect producers, intermediaries, wholesalers, retailers, and consumers. Harvesting and marketing of fish become profitable only when fishery products are sent in healthy conditions and at prices that are acceptable to consumers [19]. Moreover, IT can be used to access and communicate fisheries information and knowledge to fishermen. Furthermore, IT can be used to transfer information and knowledge to the fishing community and provide all necessary fisheries information about various fishing activities [20], [21]. Hence, IT is become and aid for the fish marketer.

\subsection{Fish Marketing by Using IT}

As the process of creating value for consumers, marketing is not only a method to deliver the products or services, but also organize a communication interaction towards customer through various media channels [22]. As stated before, the Marketing mix usually integrated by marketers to achieve success in business. Moreover, IT brings a new development of the Marketing Mix into a new level [23]. The technology transforms an offline media (e.g. newspapers, magazines) into an interactive online media (e.g. Internet, Web, e-mail, Social media) [24].

\section{Product.}

The first " $P$ " from Marketing Mix is Product, it can be the form of both goods or services from producer into the consumers [3]. The Product by using IT has a similar essence to traditional marketing. However, IT proposes a new development of virtual marketing channels to promotes the production of goods or services, which is certainly has a smaller scope for online consumers [25]. As Product must be able to meet the consumers' needs, IT presents a rich of various information regarding fish products in a virtual form of the market. The utilization of interactive online media gives the opportunity for consumers to obtain a larger number of information about the products.

\section{Promotion.}

As related to Product, Promotion is an effort to inform the consumers about the information about goods or services from marketers through several media. Through the capabilities of IT, such as Big Data, A large database housed data collected in the form of digital media can be used for promotion purposes [22]. The emergence of "e-advertisement", as the result of development from IT and marketing sector brings many benefits. E-advertising has brought great opportunities for marketers to attract the interest of consumer negating their gender, age or community through the Internet and web-based marketing. Hence, the online and virtual promotions should be more been applied by marketers [26]-[28], in form of social media, search engine, e-mail, etc. [17], [25].

However, conducting a Promotion through IT is difficult, this due to fish is goods that are simple to decay or perish. Thus, fish marketing through IT means is highly depending on the fresh and affordable of the fish to consumers [17].

\section{Place}

The place of the sale by using IT is a site or a marketplace in the social network and the Internet. Customers can quickly get information about the products or services and comparing similar products without visiting the marketplace of the house of auction [25], [29]. Similar to the Promotion aspect, an application such as email, blog, video streaming, search engine and social media were act as the channels of marketing [17].

\section{Process}

Supply Chain is an effort to increase the marketer's competitive value to be more efficiency, which is managing the flow of the process from raw material suppliers through factories and

\section{International Journal of Science and Business Email: editor@ijsab.com Website: ijsab.com}


warehouses to the end customer [30]. Moreover, Supply Chain relies on the integration of processes across the domains of marketing channels [31], which is a series of interdependent organizations in the process of distributing goods from producers to consumers [3]. The primary concern of the fish marketing system is the existence of vary of middlemen numbers as the "interdependent organizations". Through the utilization of IT, elimination of these middlemen ensuring to helps the producers to get benefits and reducing costs [17]. Thus, consumers will get a cheaper price for the goods.

Effective use of technology is one aspect that supports the success of supply chains [31]. To sum up, Supply Chain, marketing channels, and IT are inseparable to gain more efficiency of service delivered and transaction processes.

\section{Price}

Pricing in marketing should follow the market dynamics [3], also it is formed according to the rules of classical price formation, namely: cost, customer value, and competitors [25]. The Price aspect is strongly related to the Process in marketing [32]. Hence, Price is also related to the Supply Chain and [33]. The utilization of IT provides analysis to increase the marketing decisions in giving prices, product benefits, and consumer benefits, among various other functions. Moreover, by implementing the Supply Chain concept, the operational cost of production can be minimized. IT can help provide fast and accurate information in order to help provide information on changing needs so that decisions can be made more quickly and accurately. [31].

\section{People}

People in marketing involving the consumers and all the workers from the marketers [3]. To achieve a comprehensive use of IT, users should have the ability or skill and level of knowledge in IT [34]. Thus, to integrate IT with marketing, it is required both consumers and workers with specialized skills and insights around IT things [22], [35].

\section{Physical evidence}

The Physical evidence aspect of digital marketing is the traditional physical and virtual physical. The first one is including delivery points, off-line shops and offices of the company. The second one related to to the accessibility and convenience of purchase. In this case, the application such as social media, search engine, e-mail is used as the Physical evidence [25].

\section{Previous Studies}

There are numerous study has been conducted regarding marketing and IT, including the use of IT for fish marketing purposes. Discussing Product aspect, a study conducted by the researcher [36] examined the information needs among fish farmers in Life Central Local Government Area of Osun State, South-West Nigeria. The result of the study agreed that mobile phones, radio, and the Internet are the media that usually used by the farmer to collect information about the fish product. Following, researcher [37] stated that GPS as the IT tools helps the fisherman to reduce times in finding locations while usage of sonar, and also increased their product. In addition, the fishermen from in Unguja District in Zanzibar, Tanzania claimed that IT also become an aid to obtain information and knowledge on weather condition, modern fish capturing methods, market and marketing, fish preservation and processing. Furthermore, a study conducted by [17] argued that consumers decided to use an online fish marketing method rather than other marketing strategies due to the timesaving. The utilization of social media and websites have commonly become an excuse by them to get information more rapidly. Then [38] stated that the use of the mobile phone as a part of IT tools has superior functions in marketing, fishermen in Pangkor Island. Besides, [39] also stated that the use of telephone/mobile phones is the common sources of collecting

\section{International Journal of Science and Business Email: editor@ijsab.com Website: ijsab.com}

Published By 
market information. Hence, it can be concluded that the use of IT in fish marketing presents a piece of better information regarding the product. Next, as refer to Promotion aspect, researcher [40] proposed an effective and sustainable marketing strategy to attract new customer by using IT. A promotion even can be organized by fish exhibitions by using online media. Similarly, a study conducted by [41] agreed that social media is able to deliver pieces of information to become an aid for the fishing industry in Malaysia. Matters regarding awareness of fish consumption give chances to improve the promotion of markets. Then, [42] stated that IT offers a better opportunity for China's aquaculture sector to assisting marketers to promote their product and gain more profit by means of the Internet, websites and online stores. Then again, [17] reported that websites are the most commonly used as a tool for promoting the fish products in India. More importantly, [43] reported that appropriate technology should be developed and expanded based on local feasibility to increase fish production and productivity in Nepal. Based on the previous studies, it can be concluded that IT offers a major impact on Promotion construct of Marketing Mix. Place in IT-based marketing system is virtual. As reported by [44], the Internet can be used as the auction for the perishable product such as fish. The application of IT (e.g. Internet) is able to expand the local area to around the world to conduct a transaction which is listed in the application's product catalogue. Consumers also able to obtain pieces of information regarding fish product, fishery tools, equipment, and accessories [45]. In line with this, [46] stated that the Internet is usually used by consumers to purchase foods. The fish is sold through the auction and purchased by utilizing the online media in Yeu Island, France. Researcher [47] stated that the marketplace application can be used as the intercourse between fishers and endconsumers to direct interaction. Then, IT presents information regarding the clear view of prices, demand and trends of fish product in South Africa. Furthermore, [48] argued that IT can be used to become the marketplace as one of fish marketing strategies in Kainji Lake Basin, Nigeria. To sum up, IT brings a vast Place for fish marketing with numerous information offered on it.

As related to Price construct, researcher [49] reported that the price variable has a significant effect on small fish farming businesses performance in Kelantan, Malaysia. In line with this, researcher [41] also stated that by employing social media is able to influence purchasing behaviour among consumers due to the information they obtained from it. Moreover, information about prices and availability which are posted online can be reducing the volatility of fish prices [50]. Then, [51] agreed that the employment of IT who is able to reduce price volatility in agricultural markets in enhancing the efficiency of agricultural markets. Researcher [52] reported that sharing information in IT platforms causing an efficient and equitable fish trade. Reducing the process number of middlemen have an impact on reducing wastage and volatility of fish prices. Therefore, IT can be used to help marketers to determine the precise price and cheaper for fish products. The Process aspect of marketing includes the entire steps taken from marketers to consumer, from raw material to selling product [3], [30]. Subsequently, Supply Chain-as the flow that manages the Process-helps marketers achieve strategic competitiveness and generate profits [31]. The technology of the Internet virtualized the supply chains in reckoning with perishable products (e.g. fish product) in the operational management processes by marketers, exporting fish from Norway to Brazil [53]. Monitoring, controlling, planning and optimizing marketing processes can be done in real-time through the Internet in the form of virtual objects. Similar to this, researcher [54] mentioned that IT and Enterprise Resource Planning (ERP) systems support the supply chain for distributing Norwegian fish to Japan. Complementary to this, the researcher [55] said that IT technologies can be used to monitoring the supply chain of

\section{International Journal of Science and Business Email: editor@ijsab.com Website: ijsab.com}

Published By 
fisheries. Modern IT technologies such as Cloud technology, Internet of Thing (IoT) and Big Data Analytics become the aid to upgrade and transform current fish Supply Chain management. These technologies allow improving the Process to be real-time, more intelligent, more accurate, and create flourishing shareable-information environment and collaborative working [56]. Moreover, IT also can be used to record information about fish locations and storage conditions by utilizing sensory equipment, hence it upgrading the reliable exchange of food in the supply chain [57]. Hence, it can be concluded that IT helps to reduce the role of intermediaries (e.g. marketing channels) and supply chain process in fisheries as stated by the researcher [41]. Skill and knowledge of IT are required by fisherman [58]. However, lack of training was mainly due to lack of awareness of fisherman from Maharashtra, India causing they resist to use new technology for fisheries purposes [59]. Fishermen are suggested to be able to use the technology assistance [60]. Hence, information, knowledge and skills are needed to improve their fish farming practices and improving productivity [61]. People aspect in marketing not only includes fisherman, workers and marketers but also consumers [3]. The emergence of novel technologies should be balanced with skill and bits of knowledge by the consumer [62]. Therefore, skill and knowledge among marketers and consumers were needed to establish the utilization of IT in fish marketing.

\section{Discussion}

As part of economic activities, fish marketing become the main player for the Regional Income of Indonesia, especially in North Sumatera. Indonesia's fisheries potential is very abundant and to be expected to become a leading sector of the national economy. The high plantation production makes the image of North Sumatra more inclined to the plantation sector. In fact, with a fairly extensive watershed, the fisheries sector is also very promising and has bright prospects. Moreover, the territorial waters of North Sumatra which located in the Malacca Strait and the Indian Ocean are rich in fisheries [63]. In North Sumatra, the fisheries process usually organized by auction in order to help fisherman marketing the fish catch [13]. As a transaction method in central production, the auction also assists to interact with the fisherman and middlemen. However, IT penetration in North Sumatra reached only $25 \%$. Compared to other provinces in Sumatra, it is still relatively small [64]. Various challenges and barriers will be faced for the integration of IT in fish marketing. Combination of the 7Ps of Marketing Mix and the utilization of IT offers a novel fish marketing process including Promotion, Product, Place, Price, Process, People and Physical Evidence. There are five phases involved in implementing IT in fish marketing as follows: 1) Availability of IT applications as Physical Evidence. The availability of IT tools is crucial. Mobile phones, radio, and the Internet are usually used to obtain information about fish products [36]. Thus, the development of websites, social media or mobile application should be occurred to fulfil the IT integrated marketing system; 2) IT-skill and knowledge among users. Skill and knowledge of IT are required both for fisherman, marketers, and consumers [58], [62]. A basic and general ICT training for them is required and offered at the national level by the government to increase the level of IT expertise; 3) E-advertisement to promote fish products. Advertisement plays an important role in the marketing system to create direct persuasive communication to target consumers and the community [65]. Then, the development of Eadvertising brings new chances for marketers to attract the interest of consumers towards the product [26]. Promotion through e- advertisement (e.g. Internet, social media, search engine, e-mail) can be done after the development of IT application has been accepted; 4) Globalization of fish marketing. Internet as the vast online-media is able to interact with consumers and marketers around the world [45]. The third step is to sue the marketers to

\section{International Journal of Science and Business Email: editor@ijsab.com Website: ijsab.com}

Published By 
involve in global fisheries trading through IT. Hence, it will be to increase the export value of fish in Indonesia; 5)The emergence of IT-integrated Supply Chain fish marketing. As one aspect that supports the success of supply chains [31], IT also offers the technology to help to monitor, controlling, planning and optimizing marketing processes can be done in real-time in the form of virtual objects [53]. This step expects to eliminate fisheries middlemen as the market channel and decrease the cost in order to gain greater value of prices for consumers.

\section{Conclusion}

Many countries have been adopted IT for fisheries marketing purposes. Technologies such as IoT, Big Data, websites, and social media helps the marketers to promote their product and support the Supply Chain in marketing process [17], [56]. The government should take attention to the issue regarding fish marketing as part of economic activities and Regional Income of territory [13]. Through the combination Marketing Mix and IT applications, fish marketing is expected to have an improvement and brings benefit both for communities, fishermen, marketers, and government. The article elaborates the literature review on how IT plays the role towards fish marketing in several aspects from Marketing Mix including Promotion, Product, Place, Price, Process, People and Physical Evidence. There are five phases involved to implementing IT in fish marketing, namely: (1) availability of IT applications as the Physical Evidence; (2) IT-skill and knowledge among users; (3) E-advertisement to promote fish products; (4) globalization of fish marketing; and (5) the emergence of ITintegrated Supply Chain fish marketing. The article brings a suggestion to the government of North Sumatra to stress the issue regarding IT and fish marketing.

\section{References}

[1] H. Karjaluoto, N. Mustonen, and P. Ulkuniemi, "The role of digital channels in industrial marketing communications," J. Bus. Ind. Mark., vol. 30, no. 6, pp. 703-710, 2015.

[2] R. Liu, "A REAPPRAISAL OF MARKETING DEFINITION AND THEORY," J. East. Eur. Cent. Asian Res., p. 49, 2017.

[3] G. M. Armstrong, P. Kotler, M. J. Harker, and R. Brennan, Marketing: an introduction. Pearson UK, 2018.

[4] W. D. Perreault, J. P. Cannon, and E. J. McCarthy, Basic marketing: A marketing strategy planning approach. McGraw-Hill Irwin New York, NY, 2011.

[5] A. Mintoro, "Keragaan beberapa pola usaha penangkapan ikan di laut oleh rakyat di Indonesia," 2016.

[6] I. K. Bangun, "Distribusi hasil tangkapan di pelabuhan perikanan samudera belawan sumatera utara," Institut Pertanian Bogor, 2010.

[7] J. D. Sachs, "From millennium development goals to sustainable development goals," Lancet, vol. 379, no. 9832, pp. 2206-2211, 2012.

[8] S. Zhao and C.-V. Priporas, "Information technology and marketing performance within international market-entry alliances: A review and an integrated conceptual framework," Int. Mark. Rev., vol. 34, no. 1, pp. 5-28, 2017.

[9] R. Rishika, A. Kumar, R. Janakiraman, and R. Bezawada, "The effect of customers' social media participation on customer visit frequency and profitability: an empirical investigation," Inf. Syst. Res., vol. 24, no. 1, pp. 108-127, 2013.

[10] Q. Ben Liu, E. Karahanna, and R. T. Watson, "Unveiling user-generated content: Designing websites to best present customer reviews," Bus. Horiz., vol. 54, no. 3, pp. 231-240, 2011.

[11] S. Mathews, C. Bianchi, K. J. Perks, M. Healy, and R. Wickramasekera, "Internet marketing capabilities and international market growth," Int. Bus. Rev., vol. 25, no. 4, pp. 820-830, 2016.

[12] M. Mirosłava, "The Information and Communications Technologies Applications in Fisheries Sector," Stud. I Mater. Pol. Stowarzyszenia Zarządzania Wiedzq, vol. 24, pp. 193-198, 2009.

\section{International Journal of Science and Business Email: editor@ijsab.com Website: ijsab.com}


[13] R. Rahmanta and A. Arsyad, "STRATEGI PENGELOLAAN TPI TERHADAP PENDAPATAN ASLI DAERAH DI SUMATERA UTARA," J. AGRICA, vol. 1, no. 2, pp. 77-88, 2018.

[14] J. Blythe and J. Martin, Essentials of marketing. Pearson UK, 2019.

[15] B. Booms, "Marketing strategies and organizational structures for service firms," Mark. Serv., 1981.

[16] P. Kotler, Marketing Management: A South Asian perspective. Pearson Education India, 2009.

[17] S. S. Salim, H. E. James, N. R. Athira, R. X. Smitha, A. M. Shinu, and M. Meharoof, "Assessment of Online Fish Marketing in Ernakulam District, Kerala," Asian J. Agric. Extension, Econ. Sociol., pp. $1-8,2018$.

[18] A. Bahadur, "Production and marketing of cultured fish in selected areas of Bangladesh," Fac. Agric. Econ. Rural Sociol. Bangladesh Agric. Univ. Mymensingh, 2004.

[19] M. Raihan and others, "Studies on the fish marketing system and obstacles in Jessore district, Bangladesh," University of Dhaka, 2017.

[20] A. E. Annune, C. N. Ezeani, and V. N. Okafor, "Information sources dissemination and utilization patterns of the artisanal fishery sector in Benue State, Nigeria," Adv. Res., pp. 889-905, 2014.

[21] Q. Barkatullah, P. Mubina, K. Farman, A. Chandio, R. A. Buriro, and A. Razaque, "Adoption of Information Communication Technology tools Among Fishermen," J. Am. Sci., vol. 10, no. 7, 2014.

[22] A. Gupta et al., "Clinical trial management of participant recruitment, enrollment, engagement, and retention in the SMART study using a Marketing and Information Technology (MARKIT) model," Contemp. Clin. Trials, vol. 42, pp. 185-195, 2015.

[23] G. Jackson and V. Ahuja, "Dawn of the digital age and the evolution of the marketing mix," J. Direct, Data Digit. Mark. Pract., vol. 17, no. 3, pp. 170-186, 2016.

[24] E. Brynjolfsson and L. M. Hitt, "Beyond computation: Information technology, organizational transformation and business performance," J. Econ. Perspect., vol. 14, no. 4, pp. 23-48, 2000.

[25] E. Pogorelova, I. Yakhneeva, A. Agafonova, and A. Prokubovskaya, "Marketing Mix for Ecommerce," Int. J. Environ. Sci. Educ., vol. 11, no. 14, pp. 6744-6759, 2016.

[26] S. Bhakar, S. Bhakar, K. Kushwaha, and others, "The Effectiveness of E-Advertisement towards Customer Purchase Intention: Indian Perspective," Available SSRN 3315066, 2019.

[27] D. A. Al Qudah, A. I. Cristea, S. H. Bazdarevic, S. Al-Saqqa, A. Rodan, and W. Yang, "Personalized eadvertisement and experience: recommending user-targeted ads," in 2015 IEEE 12th International Conference on e-Business Engineering, 2015, pp. 56-61.

[28] M. M. Chaturvedi, "A Conceptual Study on Recent Trends, Challenges and Opportunities in EMarketing:-in Special Reference with 7 Up Case Study," group, 2018.

[29] Y. Durmaz and I. H. Efendioglu, "Travel from traditional marketing to digital marketing," Glob. J. Manag. Bus. Res., 2016.

[30] S. Devaraj, L. Krajewski, and J. C. Wei, "Impact of eBusiness technologies on operational performance: the role of production information integration in the supply chain," J. Oper. Manag., vol. 25, no. 6, pp. 1199-1216, 2007.

[31] I. V Kozlenkova, G. T. M. Hult, D. J. Lund, J. A. Mena, and P. Kekec, "The role of marketing channels in supply chain management," J. Retail., vol. 91, no. 4, pp. 586-609, 2015.

[32] F. B. Norwood and J. L. Lusk, Agricultural marketing and price analysis. Waveland Press, 2018.

[33] M. Formentini and P. Romano, "Towards supply chain collaboration in B2B pricing: A critical literature review and research agenda," Int. J. Oper. Prod. Manag., vol. 36, no. 7, pp. 734-756, 2016.

[34] N. Akbar, V. Ratnawati, and V. Novita, "Pengaruh pengetahuan teknologi informasi, pemanfaatan teknologi informasi, dan faktor kesesuaian tugas-teknologi terhadap kinerja akuntan internal," J. Ekon., vol. 18, no. 02, 2013.

[35] T. H. Nguyen, M. Newby, and M. J. Macaulay, "Information technology adoption in small business: Confirmation of a proposed framework," J. Small Bus. Manag., vol. 53, no. 1, pp. 207227, 2015.

[36] E. J. Ijatuyi, O. A. Abiolu, and O. A. Olaniyi, "Information needs of fish farmers in Osun-State,

\section{International Journal of Science and Business} Email: editor@ijsab.com Website: ijsab.com

Published By 
Nigeria," J. Hum. Ecol., vol. 56, no. 3, pp. 309-317, 2016.

[37] R. Benard and F. W. Dulle, "Application of ICT tools in communicating information and knowledge to artisanal fishermen communities in Zanzibar," 2017.

[38] M. D. Bahtiar, "THE INFLUENCE OF LOCUS OF CONTROL, SELF-EFFICACY, AND ACCOUNTING ACHIEVEMENT LEARNING ON ACCOUNTING CAREER MATURITY OF THE TWELFTH GRADE STUDENTS OF THE ACCOUNTING PROGRAM IN PRIVATE VOCATIONAL HIGH SCHOOLS," Int.J. Educ., vol. 10, no. 1, pp. 53-59, 2017.

[39] M. S. Islam, M. S. Islam, A. Bhadra, S. Sharmin, and M. R. R. Sardar, "Fish marketing system and livelihood status of fish traders in Ishwarganj Upazila under Mymensingh district," 2018.

[40] L. Mayoza, A. Agus, W. Lili, and A. Rizal, "ANALYTICAL BUSINESS DEVELOPMENT ON NEON TETRA (PARACHEIRODON INNESI) ORNAMENTAL FISH CULTIVATION,” GSJ, vol. 6, no. 7, p. 938, 2018.

[41] A. S. Ismail and H. Khalid, "Fishing'for content in Social Media: A Qualitative Approach," Procedia Comput. Sci., vol. 72, pp. 406-413, 2015.

[42] J. Peng, "Design and promotion strategy of marketing platform of aquatic auction based on Internet," Phys. Procedia, vol. 33, pp. 1269-1274, 2012.

[43] N. P. Karki and others, "Fish farming in Nepal: trends, opportunities and constraints," Nepal. J. Agric. Sci., pp. 201-210, 2016.

[44] X. Kong, G. Q. Huang, H. Luo, and B. P. C. Yen, "Physical-internet-enabled auction logistics in perishable supply chain trading: State-of-the-art and research opportunities," Ind. Manag. Data Syst., vol. 118, no. 8, pp. 1671-1694, 2018.

[45] H. A. E. Widjaja and others, "E-commerce implementation to support ornamental fish breeders in Indonesia," in 2015 International Conference on Information Technology Systems and Innovation (ICITSI), 2015, pp. 1-7.

[46] F. Salladarré, P. Guillotreau, G. Debucquet, and G. Lazuech, "Some Good Reasons for Buying Fish Exclusively From Community-Supported Fisheries: The Case of Yeu Island in France," Ecol. Econ., vol. 153, pp. 172-180, 2018.

[47] M. Petrik and D. Serge Raemakers, "The Case for Supporting Small-Scale Fisheries Governance Through ICT," 2018.

[48] G. O. Nwabeze, S. Faleke, M. Tanko, and Y. Y. Malgwi, "Strategies Use by Smoked Fish Marketers in Kainji Lake Basin, Nigeria," J. Agric. Ext., vol. 23, no. 1, pp. 54-65, 2019.

[49] A. W. Fitriah et al., "The Effects of Marketing Mix on Small Fish Farming Business Performance," Rev. Publicando, vol. 6, no. 19, pp. 1-16, 2019.

[50] N. Ejiogu-Okereke, J. Chikaire, E. Ogueri, and N. Chikezie, "Roles of Information and Communications Technologies in Improving Fish Farming and Production in Rivers State, Nigeria.," Libr. Philos. Pract. (e-journal). Pap., vol. 1445, 2016.

[51] E. Nakasone and M. Torero, "A text message away: ICTs as a tool to improve food security," Agric. Econ., vol. 47, no. S1, pp. 49-59, 2016.

[52] C. M. Aura et al., "Using fish landing sites and markets information towards the quantification of the blue economy to enhance fisheries management," Fish. Manag. Ecol., vol. 26, no. 2, pp. 141$152,2019$.

[53] C. N. Verdouw, J. Wolfert, A. J. M. Beulens, and A. Rialland, "Virtualization of food supply chains with the internet of things," J. Food Eng., vol. 176, pp. 128-136, 2016.

[54] P. Engelseth, T. Takeno, and K. Alm, "Food safety, quality and ethics in supply chains: a case study of informing in international fish distribution," in The Crisis of Food Brands, Routledge, 2016, pp. 75-94.

[55] A. Ciaghi and A. Villafiorita, "Beyond food sharing: Supporting food waste reduction with ICTs," in 2016 IEEE International Smart Cities Conference (ISC2), 2016, pp. 1-6.

[56] R. Zhong, X. Xu, and L. Wang, "Food supply chain management: systems, implementations, and future research," Ind. Manag. Data Syst., vol. 117, no. 9, pp. 2085-2114, 2017.

[57] A. Kamilaris, A. Fonts, and F. X. Prenafeta-Bold\$ \acute \nu\$, "The Rise of the Blockchain Technology in Agriculture and Food Supply Chain." 2018.

\section{International Journal of Science and Business} Email: editor@ijsab.com Website: ijsab.com 
[58] S. Gunakar and R. Bhatta, "Socioeconomic status of Fisher-women in segmented fish markets of coastal Karnataka," Agric. Econ. Res. Rev., vol. 29, no. 347-2016-17252, pp. 253-266, 2016.

[59] B. Patilkhede, V. G. Patil, and J. R. Kadam, "Technological, situational and policy constraints faced by fishermen in coastal Konkan region of Maharashtra," J. Pharmacogn. Phytochem., vol. 7, no. 2, pp. 537-540, 2018.

[60] E. Wantah, E. T. Djatmika, M. Witjaksono, and H. Wahyono, "Need Analysis of Coastal Fisherman empowerment Based on Economics education and Potential Coastal in Minahasa Regency of North Sulawesi," in IOP Conference Series: Earth and Environmental Science, 2018, vol. 156, no. 1, p. 12026.

[61] R. Benard, F. Dulle, and H. Lamtane, "The influence of ICT usage in sharing information on fish farming productivity in the southern highlands of Tanzania," 2018.

[62] G. Kumar, C. Engle, and C. Tucker, "Factors driving aquaculture technology adoption," J. world Aquac. Soc., vol. 49, no. 3, pp. 447-476, 2018.

[63] A. Suman, H. E. Irianto, F. Satria, and K. Amri, "Potensi dan tingkat pemanfaatan sumber daya ikan di Wilayah Pengelolaan Perikanan Negara Republik Indonesia (WPPNRI) Tahun 2015 serta opsi pengelolaannya," J. Kebijak. Perikan. Ind, vol. 8, no. 2, pp. 97-110, 2016.

[64] A. H. Lubis, S. Z. S. Idrus, and A. Sarji, "ICT Usage Amongst Lecturers and Its Impact Towards Learning Process Quality," vol. 34, no. 1, pp. 284-299, 2018.

[65] J. C. Andrews and T. A. Shimp, Advertising, promotion, and other aspects of integrated marketing communications. Nelson Education, 2017.

\section{Cite this article:}

Arsyad Lubis, Muhammad Akbar Siregar, Maksyum Syahri Lubis \& Andre Hasudungan Lubis (2019). Does Information Technology Help Fish Marketing? A Review for A Preferability Fish Marketing in North Sumatera, Indonesia. International Journal of Science and Business, 3(4), 105-115. doi: https://doi.org/10.5281/zenodo.3346913

Retrieved from http://ijsab.com/wp-content/uploads/379.pdf

\section{Published by}

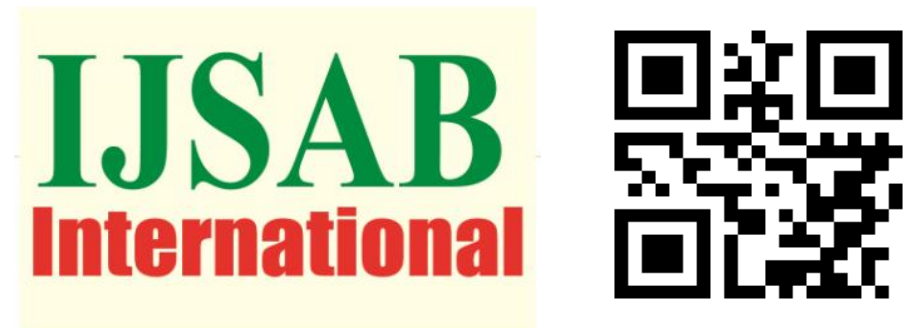

\section{International Journal of Science and Business Email: editor@ijsab.com Website: ijsab.com}

